\title{
UPAYA NON-PENAL DALAM PEMBERANTASAN TINDAK PIDANA KORUPSI
}

\author{
Mochamad Ramdhan Pratama ${ }^{1}$, Mas Putra Zenno Januarsyah ${ }^{2}$ \\ ${ }^{1}$ Magister Ilmu Hukum Universitas Diponegoro, Semarang. \\ ${ }^{2}$ Sekolah Tinggi Hukum Bandung, Bandung. \\ putrazenno@gmail.com
}

\begin{abstract}
Abstrak
Penelitian ini bertujuan untuk mengkaji secara jelas mengenai upaya non-penal dalam pemberantasan tindak pidana korupsi. Korupsi di Indonesia bukan sekedar persoalan normatif, akan tetapi sudah menjadi penyakit kolosal. Urgensi penelitian ini berkofus pada upaya non-penal dengan strategi perubahan sosial dengan mengubah cara berpikir masyarakat di lingkungan sekitar. Metode penelitian bersifat deskriptif (descriptive research), jenis penelitian kriminologis dengan pendekatan konseptual (conceptual approach). Hasil dari penelitian ini dapat dikonklusikan bahwa sarana non-penal memiliki nurani intelektual yang berfokus pada perbaikan kondisi sosial yang mempunyai pengaruh previntif terhadap kejahatan melalui perwujudan pendidikan anti korupsi sebagai kunci utama.
\end{abstract}

Kata Kunci: Korupsi; Non-Penal; Pendidikan Antikorupsi; Perubahan Sosial

1 Mahasiswa Pascasarjana Program Studi Magister Ilmu Hukum Universitas Diponegoro

2 Dosen Sekolah Tinggi Hukum Bandung 


\title{
NON-PENAL EFFORTS IN ERADICATING CORRUPTION
}

\author{
Mochamad Ramdhan Pratama1, Mas Putra Zenno Januarsyah ${ }^{2}$ \\ ${ }^{1}$ Master of Law, Diponegoro University, Semarang. \\ ${ }^{2}$ Sekolah Tinggi Hukum Bandung, Bandung. \\ putrazenno@gmail.com
}

\begin{abstract}
This study aims to examine clearly the non-penal efforts in eradicating criminal acts of corruption. Corruption in Indonesia is not just a normative issue, but has become a colossal disease. The urgency of this research focuses on non-penal efforts with social change strategies by changing the way of thinking of people in the surrounding environment. The research method is descriptive (descriptive research), a type of criminological research with a conceptual approach. The results of this study can be concluded that non-penal means have an intellectual conscience that focuses on improving social conditions that have a prevailing influence on crime through the realization of anti-corruption education as the main key.
\end{abstract}

Keywords: Corruption, Non-Penal, Anti-Corruption Education, Social Change 


\section{PENDAHULUAN}

\section{A. Latar Belakang}

Berpangkal pada penelitian yang dilakukan oleh Herman, dengan judul upaya non penal dalam penanggulangan tindak pidana korupsi. Esensi penelitiannya adalah model pencegahan tindak pidana korupsi dalam perspektif hukum pidana dengan pendekatan non-penal yang fokus utamanya pada upaya preventif yang menekankan pada usaha pencegahan korupsi yang diarahkan untuk meminimalkan penyebab dan peluang untuk dilakukannya tindak pidana korupsi, sehingga model pencegahan yang dapat dilakukan adalah penataan kualitas Sumber Daya Manusia (selanjutnya disebut SDM), penataan manajemen kerja pada instansi dan organisasi, optimalisasi peran satuan pengawas internal instansi dan organisasi, peningkatan peran serta masyarakat, dan penataan Undang-Undang dan perbaikan SDM aparat penegak hukum. ${ }^{3}$

Penelitian ini berkaitan dengan penelitian Rangga Jayanuarto, dalam penelitiainnya membahas kebijakan non penal (penanggulangan korupsi) berdimensi transendental, esensi penelitian tersebut menjelaskan bahwa kejahatan korupsi merupakan extra ordinary crime (kejahatan yang luar biasa), oleh karena itu cara menanggulangi pun juga harus dengan cara-cara yang luar biasa karena korupsi meruapakan kejahatan yang merugikan negara dan berakibat pada tidak stabilnya keadilan dan kesejahteraan yang dirasakan masyarakat. Oleh karenanya salah satu upaya luar biasa tersebut adalah dengan memasukkan dimensi transendental pada kebijakan non penal penanggulangan korupsi sehingga upaya yang dilakukan juga melampaui batas sejalan dengan korupsi yang juga merupakan kejahatan yang melampaui batas. ${ }^{4}$

Lebih dari itu terdapat juga penelitian yang dilakukan oleh Japansen Sinaga dengan judul kebijakan penegakan hukum dalam tindak pidana korupsi berdasarkan

${ }^{3}$ Herman, "Upaya Non Penal dalam Penanggulangan Tindak Pidana Korupsi", Horlev Volume 2 Issue 1 March 2018, Fakultas Hukum Universitas Halu Oleo, 2018, Kendari, hal 313 DOI: http://dx.doi.org/10.33561/holrev.v2i1.4192

4 Rangga Jayanuarto, “Kebijakan Non Penal (Penanggulangan Korupsi) Berdimensi Transendental", Prosiding Seminar Nasional 2018, Universitas Muhammadiyah Surakarta, 2018, Surakarta, hal 390. http://hdl.handle.net/11617/9712 
pendekatan non-penal, esensi dalam penelitian tersebut menjelaskan bahwa penyebab lemahnya pemberantasan korupsi di Indonesia, terutama di daerah, selain masih kurang jumlah penegak hukum yang berwawasan hukum luas, penegak hukum yang berani berbenturan dengan kekuasaan juga masih kurang. Penegak hukum hanya berani pada pelaku yang sudah lemah kekuasaannya, mantan pejabat, atau pengusaha yang tidak ada back up kekuasaan yang kuat, sehingga terkesan seperti tebang pilih pelaku korupsi yang dihadapkan ke peradilan. ${ }^{5}$ Penelitian di atas memberikan peneliti referensi dalam memperkaya bahan kajian pada penelitian ini. Kelebihan dalam penelitian ini menjelaskan upaya non-penal dengan strategi perubahan sosial yang berfokus pada strategi mengubah cara berpikir masyarakat dalam pemberantasan tindak pidana korupsi. Penelitian ini melengkapi penelitian sebelumnya yang membahas atau berkorelasi dengan judul variabel penelitian.

Harus disadari meningkatnya tindak pidana korupsi yang tidak terkendali akan membawa dampak yang tidak hanya sebatas kerugian negara dan perekonomian nasional tetapi juga pada kehidupan berbangsa dan bernegara. Perbuatan tindak pidana korupsi merupakan pelanggaran terhadap hak-hak sosial dan hak-hak ekonomi masyarakat, sehingga tindak pidana korupsi tidak dapat lagi digolongkan sebagai kejahatan biasa (ordinary crimes) melainkan telah menjadi kejahatan luar biasa (extra-ordinary crimes). Sehingga dalam upaya pemberantasannya tidak lagi dapat dilakukan "secara biasa," tetapi "dituntut cara-cara yang luar biasa (extra-ordinary enforcement)."6

Sedangkan dalam penelitian Tamala Sari Martha Prakoso membedakan antara unsur-unsur tindak pidana korupsi dalam Pasal 2 UU PTPK dengan unsurunsur tindak pidana korupsi dalam Pasal 3 UU PTPK ialah pada unsur memperkaya diri sendiri atau orang lain atau suatu korporasi dan unsur secara

\footnotetext{
${ }^{5}$ Japansen Sinaga, “Kebijakan Penegakan Hukum Dalam Tindak Pidana Korupsi Berdasarkan Pendekatan Non-Penal”, Jurnal Law Pro Justitia Vol. II, No. 2 - Juni 2017, Fakultas Hukum Universitas Pelita Harapan, 2017, Medan, hal 39.

${ }^{6}$ Mas Putra Zenno Januarsyah, "Penerapan Prinsip Ultimum Remedium dalam Tindak Pidana Korupsi Kajian Putusan Nomor 2149 K/Pid.Sus/2011”, Jurnal Yudisial Vol 10 No 3 Desember 2017, Komisi Yudisial, 2017, Jakarta, hal 264. http://dx.doi.org/10.29123/jy.v10i3.266
} 
melawan hukum dalam Pasal 2 UU PTPK dibandingkan dengan unsur menguntungkan diri sendiri atau orang lain atau korporasi dan unsur menyalahgunakan kewenangan, kesempatan atau sarana yang ada padanya karena jabatan atau kedudukan dalam Pasal 3 UU PTPK. Sementara itu unsur setiap orang, dapat merugikan keuangan negara dan secara bersama-sama sebagai orang yang melakukan, menyuruh lakukan, atau yang turut serta melakukan, tidak terdapat perbedaan antara Pasal 2 dan Pasal 3 UU PTPK. ${ }^{7}$ Berelasi dengan hal tersebut, maka korupsi bukan sekedar persoalan normatif saja, akan tetapi sudah menjadi penyakit kolosal. Sehingga korupsi sudah menjadi musuh masyarakat karena bisa menghancurkan sendi-sendi kehidupan bangsa. Kegagalan hukum modern saat ini yang berkamuflase pada liberal kapitalistik tidak mampu menyelesaikan secara komprehensif kasus-kasus tindak pidana korupsi yang berelasi dengan pejabat tinggi atau elit politik.

Melihat hal-hal di atas seyogyanya pemerintah melakukan usaha yang rasional dalam menanggulangi kejahatan melalui pendekatan perundangundangan maupun pendekatan pencegahan. Menurut Barda Nawawi Arief suatu kebijakan atau upaya penanggulangan tindak pidana pada hakikatnya merupakan bagian integral dari upaya perlindungan masyarakat (social defence) guna mencapai kesejahteraan masyarakat (social welfare). ${ }^{8}$ Apabila ditinjau dari sudut pandang politik kriminal, maka keseluruhan kegiatan preventif yang berelasitas dengan kebijakan sosial atau pembangunan nasional untuk memperbaiki kondisi sosial tertentu seperti penyatuan dan pendidikan sosial dalam rangka mengembangkan tanggung jawab sosial warga masyarakat, penggarapan kesehatan jiwa masyarakat melalui pendidikan moral, agama, atau

\footnotetext{
${ }^{7}$ Tamala Sari Martha Prakoso, "Pemenuhan Unsur Memperkaya Diri Sendiri Atau Orang Lain Atau Korporasi Dalam Pasal 2 UU Nomor 31 Tahun 1999 Dan Unsur Menguntungkan Diri Sendiri Atau Orang Lain Atau Korporasi Dalam Pasal 3 UU Nomor 31 Tahun 1999 Pada Putusan Hakim Perkara Tindak Pidana Korupsi (Studi Putusan Nomor 238/Pid.b/2009/PN.Kray jo. Nomor 373/Pid.b/2010/PT.Smg jo. Nomor 167k/Pid.sus/2011 di Pengadilan Negeri Karanganyar)", Recidive Volume 3 No 1 Januari-April 2014, Fakultas Hukum Universitas Sebelas Maret, 2014, Surakarta, hal 22.

${ }^{8}$ Barda Nawawi Arief, "Bunga Rampai Kebijakan Hukum Pidana Perkembangan Penyusunan Konsep KUHP baru”, Genta Publishing, 2010, Jakarta, hal 4.
} 
yang bersifat moralistik lainnya yang secara tidak langsung mempunyai pengaruh preventif terhadap kejahatan.

Berpangkal dari pendapat Marc Ancel, mengemukakan bahwa politik kriminal dapat diberikan pengertian sebagai "the rational organization of the control of crime by society". Definisi tersebut tidak berbeda dengan pendapat G. Peter Hoefnagels yang menyatakan bahwa "criminal policy is the rational organization of the social reaction to crime". ${ }^{9}$ Hal ini berarti dapat dirumuskan bahwa politik kriminal merupakan suatu usaha yang rasional dari masyarakat dalam penanggulangan kejahatan.

G. Peter Hoefnagels menggambarkan untuk menanggulangi kejahatan, kebijakan kriminal dapat dijabarkan dalam berbagai bentuk antara lain: ${ }^{10}$

a. Penerapan hukum pidana (criminal lawapplication);

b. Pencegahan tanpa pidana (prevention without punishment); dan

c. Mempengaruhi pandangan masyarakat mengenai kejahatan dan pemidanaan lewat mass media (influencing views of society on crime andpunishment).

Perlu ditegaskan bahwa sebagai suatu kesatuan dalam keseluruhan mekanisme penanggulangan kejahatan, maka harus ada jalinan mata rantai antara setiap tahap pemidanaan, hal ini berarti tahap pemberian pidana tidak dapat dilepaskan dari tahap penetapan pidana dan tahap pelaksanaan pidana yang menjadi kebijakan eksekutif. Perlu juga diingat, bahwa yang menjalin ketiga tahap pemidanaan itu sehingga menjadi satu kesatuan dari tujuan pemidanaan. Oleh karena itu dalam tahap pemberian pidana, harus dihayati adalah tujuan pemidanaan yang berlatar belakang filsafat pemidanaan. ${ }^{11}$

Refleksi di atas, memberikan suatu pemahaman bahwa harus adanya jalinan mata rantai antara kebijakan yang menetapkan jumlah sanksi pidana oleh pembuat undang-undang dengan kebijakan dijatuhkan pidana itu secara konkret oleh hakim. Namun hal ini tidak berarti jika jumlah maksimum pidana yang ditetapkan oleh pembuat undang-undang harus sama dengan yang dijatuhkan

${ }^{9}$ Marc Ancel dalam Barda Nawawi Arief, ibid., hal 3.

${ }^{10} \mathrm{G}$. Peter Hoefnagels dalam Barda Nawawi Arief, ibid., hal 5

${ }^{11}$ Widiada Gunakaya, "Politik Kriminal”, STHB, 1997, Bandung, hal 89. 
oleh hakim. Akan tetapi sebaliknya juga, tidak berarti juga bahwa kebebasan hakim itu boleh terlalu jauh berbeda dari kebijakan strategi pidana yang telah ditetapkan.

Penelitian ini melengkapi penelitian sebelumnya tentang bagaimana penanganan tindak pidana korupsi baik melalui upaya penal maupun non penal. Pokok permasalahan dalam penelitian ini adalah berkisar pada masalah politik kriminal di bidang korupsi, karena setiap usaha yang bersifat rasional untuk menanggulangi kejahatan, pada hakikatnya merupakan bidang kajian politik kriminal. Hanya saja, permasalahan pokok tadi lebih berspektrum pada permasalahan criminal policy by non-penal. Tujuan dari penelitian ini adalah mengkaji secara jelas mengenai upaya non-penal dalam pemberantasan tindak pidana korupsi.

\section{B. Perumusan Masalah}

Merujuk pada latar belakang di atas, permasalahannya yang dapat dirumuskan dalam penelitian ini adalah bagaimanakah upaya non-penal dalam pemberantasan tindak pidana korupsi?

\section{Metode Penelitian}

Penelitian ini bersifat deskriptif dengan jenis penelitian pendekatan yuridis normatif, penelitian yuridis normatif dilakukan melalui penelitian kepustakaan yang meneliti data sekunder berupa bahan hukum primer, bahan hukum sekunder, dan bahan hukum tersier, dengan pendekatan konseptual (conceptual approach). Pendekatan konseptual adalah pendekatan yang memberikan sudut pandang analisa penyelesaian permasalahan dalam penelitian hukum dilihat dari aspek konsep-konsep hukum.

Metode analisis data yang digunakan dalam penelitian ini adalah metode kualitatif, yakni analisis data dengan cara menguraikan data secara bermutu dalam bentuk kalimat yang teratur, runtun, logis, tidak tumpang tindih, dan efektif, sehingga memudahkan interpretasi data dan pemahaman hasil analisis. 


\section{PEMBAHASAN}

\section{Upaya Non-Penal Dalam Pemberantasan Tindak Pidana Korupsi}

Korupsi menjadi salah satu masalah besar yang dihadapi Indonesia, bahkan telah kronis. Zainuri mengungkapkan bahwa korupsi di negeri ini merambah semua lini bagaikan gurita. Penyimpangan ini bukan saja merasuki kawasan yang sudah dipersepsi publik sebagai sarang korupsi, tetapi juga menyusuri lorong-lorong instansi yang tidak terbayangkan sebelumnya bahwa di sana ada korupsi. Satu per satu skandal keuangan di berbagai instansi negara terbongkar. ${ }^{12}$

Kajian tentang korupsi di Indonesia sudah banyak disampaikan kepada publik, baik melalui diskusi, seminar, hasil survei, media masa dan sebagainya. Salah satu kajian dan survei rutin tentang korupsi dilakukan oleh salah satu lembaga independen yaitu Transparency International (selanjutnya disebut TI). ${ }^{13}$ Hasil survei yang dilakukan oleh badan yang berwenang tersebut memberikan skor 38 bagi Indonesia. ${ }^{14}$

Usaha rasional dalam menanggulangi kejahatan dapat dilakukan dengan menggunakan 2 (dua) sarana, yaitu dengan sarana penal (hukum pidana), dan non-penal (non hukum pidana), yang dalam pelaksanaannya merupakan satu kesatuan integratif dan bersinergi dengan kebijakan yang lebih besar yaitu kebijakan sosial. Terkait dengan penelitian ini adalah penggunaan sarana penal, yakni pembuatan dan perumusan hukum pidana (UU PTPK) yang baik, diharapkan tindak pidana korupsi dapat ditanggulangi dengan baik pula.

Kelemahan-kelemahan formulasi tindak pidana korupsi saat ini ialah Kebijakan hukum pidana dalam hal pemberantasan tidak pidana korupsi, masih

${ }^{12}$ Zainuri dalam Mas Putra Zenno Januarsyah, op.cit., hal 264.

${ }^{13}$ Achmad Badjuri, loc.cit.

${ }^{14}$ Transparansi International, Corruption Percep tion Index, https://ti.or.id/corruptionpercep tionindex-2018/, diakses 18 April 2020. 
tersebar di beberapa perundang-undangan, hal ini dapat menimbulkan persoalan terutama dalam aspek keadilan. ${ }^{15}$

Ekspektasi rakyat kepada pemerintah bukan hanya membentuk suatu aturan-aturan normatif semata, akan tetapi eksistensi pemerintah secara aktif dalam menciptakan suasana pemerintahan yang terbuka, berintegritas, dan segala kebijakan yang hasilnya untuk kepentingan rakyat. Oleh karena itu jabatan-jabatan penting di dalam sistem ketatanegaraan Indonesia harus dijabat oleh orang-orang yang mempunyai softskill dan hardskill yang baik, serta tidak menyalahgunakan otoritasnya untuk kepentingan pribadi.

Pemerintah dalam hal penanganan tindak pidana korupsi mempunyai usaha rasional melalui pendekatan upaya penal (represif) dengan pemberian sanksi kepada subjek hukum yang melakukan tindak pidana. Sehingga, pemberian sanksi terhadap tindak pidana korupsi merupakan reaksi atas perbuatan korupsi yang dilakukan. Namun demikian dalam proses penanggulangan tindak pidana termasuk tindak pidana korupsi tidak hanya menggunakan upaya penal yang cenderung reaktif, akan tetapi juga harus ada upaya non-penal dengan pendekatan preventif dengan jalan pencegahan seseorang melakukan tindak pidana.

Penanggulangan kejahatan melalui non-penal harus dilakukan karena sarana penal memiliki kelemahan atau ketidakmampuan hukum pidana dari sudut berfungsinya atau bekerjanya hukum (sanksi) pidana itu sendiri. Sedangkan apabila ditinjau dari kejahatan sebagai sosial, maka banyak faktor yang menyebabkan terjadinya suatu kejahatan. Wajarlah hukum pidana mempunyai keterbatasan kemampuan untuk menanggulangi seperti yang dikatakan sudarto bahwa penggunaan hukum pidana merupakan penanggulangan secara gejala (Kuren am Symton) dan bukan suatu penyelesaian dengan menghilangkan sebab-sebabnya. Meniscayakan langkah-

15 Andi Febriansyah Al Sabah AZ, Kebijakan Hukum Pidana Dalam Pemberantasan Tindak Pidana Korupsi, Jurnal Al Daulah Vol 6 No 1, Universitas Islam Negeri Alaudin, 2017, Makassar, hal 206. http://dx.doi.org/10.24252/ad.v6i1.4875 
langkah penanggulangan kejahatan dengan sarana non-penal maka proses perwujudannya melalui pendidikan yang mempunyai peran kunci.

Sarana non-penal memiliki nurani intelektual yang berfokus pada perbaikan kondisi sosial, namun secara implisit mempunyai pengaruh previntif terhadap kejahatan. Usaha-usaha non-penal ini, misalnya penyantunan dan pendidikan sosial dalam rangka mengembangkan tanggung jawab sosial warga masyarakat, penggarapan kesehatan jiwa masyarakat melalui pendidikan moral, agama, atau yang bersifat moralistik lainnya, peningkatan usaha-usaha kesejahteraan anak dan remaja, kegiatan patroli dan pengawasan lainnya. Tidak kalah pentingnya mengenai meningkatkan usaha-usaha yang bersifat abolionistik, yaitu usaha-usaha yang dapat mengikis habis secara langsung faktor-faktor kondusif penyebab kejahatan.

Sejalan dengan hal di atas, United Nations Office on Drugs and Crime (selanjutnya disebut UNODC) dalam buku ANTI-CORRUP TION EDUCATION AT SCHOOL Methodical material for general and higher education schools mempunyai program pendidikan anti korupsi di sekolah yaitu: ${ }^{16}$

An anti-corruption movement is heavily emotional. Emotions are not bad, although sometimes they mean that protestors have very superficial and vague knowledge about the phenomenon they disapprove of and, as a result, they fail to change anything in principle. Bearing this in mind, one of the key tasks of anti-corruption education at school is to provide knowledge in order to:

a. Teach how to recognise corruption (and separate it from other types of crime);

b. Provide arguments why corruption is evil;

c. Demonstrate means of reducing corruption.

Provision and obtaining of information for anti-corruption education may be carried out in the same way as for the other social disciplines which include

${ }^{16}$ UNODC, "ANTI-CORRUPTION EDUCATION AT SCHOOL Methodical Material For General And Higher Education Schools", UNODC, 2006, Wina, hal 26. 
lectures; analysis of various written sources of information (articles, survey reports, historical sources); discussions with various people (law enforcement officials, witnesses, politicians and civil servants); review of video material, etc. Yet when dealing with anti-corruption education, there is always a threat that mere provision of information can turn into a methodological material of training young people about the possibilities of corrupt conduct or contribute to tearing up the fabric of society we live in and its institutions. Therefore, provision of information should be done in a moderate and tasteful manner, bearing in mind that the key objective is not to gain the most knowledge but to make the best judgement.

Attitude is an evaluative disposition toward some object based upon cognitions, affective reactions, behavioural intentions and past behaviours. For example:

a. Behaviour "I paid the public official in order to...";

b. Intentions "I should 'grease the palm' of Mr. Z to keep him quiet";

c. Attitude "The fight against corruption is a funny and senseless thing, though...";

d. Cognitions "I have to take care of bribes all the time to make it smooth and so do the people I know";

e. Affective Reactions "To tell you the truth, it is disgusting to 'grease somebody's palm' every time I have to solve something"

Pada prinsipnya apa yang dijelaskan di atas memuat suatu relasitas anatara setiap elemen. Perubahan dalam satu elemen dapat meminta perubahan pada yang lain. Misalnya, mengubah niat perilaku dan perilaku dapat mengubah kognisi, reaksi afektif, dan sikap.

Apabila ditinjau dari konsep tenaga pengajar, seperti seorang guru atau dosen, maka seharusnya memberikan informasi tentang bahaya laten dari korupsi, pengembangan sikap dasar siswa atau mahasiswa harus dilakukan ketika memasuki dunia pendidikan. Pencapaian informasi yang dapat direalisasikan dalam pemahaman mengenai kerugian yang diakibatkan oleh perbuatan korupsi dengan menggunakan argumen keilmuan baik bidang ekonomi, sosial, hukum, politik, dan budaya. Oleh karena itu, setiap argumen harus transformasikan ke dalam bahasa lebih mudah untuk menunjukkan 
bahwa perbuatan korupsi mengancam kepentingan kehidupan. Penyampaian informasi yang diberikan kepada siswa atau mahasiswa harus diberikan secara kreatif dan inovatif. Setelah disampaikan informasi pengetahuan tentang bahaya laten dari perbuatan korupsi, maka tugas selanjutnya diemban oleh para agen perubahan yaitu mahasiswa. Mahasiswa menyampaikan kembali kepada masyarakat betapa bahayanya perbuatan korupsi dalam kepentingan kehidupan. Pemeberian informasi kepada masyarakat dapat dilakukan melalui dialog, Kuliah Kerja Nyata, Bina Desa, dan lain sebagainya dalam bentuk pengabdian kepada masyarakat.

Perubahan sosial masyarakat dapat terjadi apabila mengubah cara berpikir masyarakat itu sendiri. Mengubah cara berpikir masyarakat bisa dilakukan dengan konsep pedagogi antikorupsi. Untuk itu pedagogi antikorupsi diartikan sebagai pendidikan koreksi budaya yang bertujuan untuk mengenalkan cara berpikir dan nilai-nilai baru kepada masyarakat. ${ }^{17}$

Konsep Pedagogi antikorupsi dapat dilaksanakan di semua jalur pendidikan baik formal, nonformal maupun informal. Akan tetapi yang mempunyai otoritas dan kultur yang jelas adalah jalur formal yang sampai saat ini dipandang efektif untuk menyiapkan generasi muda berperilaku antikorupsi. Lebih dari itu pada tingkat informal, seperti kegiatan ekstra kurikuler dipandang lebih efektif karena suasana penyampaiannya tidak formal seperti dikelas. ${ }^{18}$

Sinergi dengan pemikiran di atas, fokus utama pedagodi antikorupsi adalah membentuk kesadaran diri pribadi, maka lingkungan yang paling menguntungkan untuk itu adalah disiplin sosial, termasuk pendidikan Ilmu Hukum, Sejarah, Politik, Kewarganegaan, dan Etika. Interdisipliner ilmu tersebut, mempunyai peranan dalam menjelaskan bahaya laten dari perbuatan korupsi. Apabila penyampaian informasi diterima dengan baik oleh para agen

${ }^{17}$ Totok Suyanto, "Pendidikan Anti Korupsi dan Pengembangan Budaya Sekolah", JPIS Vol 23 No 8 Edisi Juli - Desember 2005, Jurnal Pendidikan Ilmu Sosial, 2005, Bandung, hal 43.

${ }^{18}$ Eko Handoyono, "Pendidikan Anti Korupsi”, Ombak, 2013, Yogyakarta, hal 44. 
perubahan, maka satu langkah awal telah tercapai untuk mengubah cara berpikir masyarakat.

Konsep pedagogi antikorupsi dalam jenjang pendidikan di Indonesia harus diatur secara jelas dan tidak menimbulkan interprestasi ganda oleh penerima atau pembaca. Sebagai contoh yang bisa diberikan dalam pembelajaran anti korupsi pada tingkatan Siswa Dasar (SD) teknik mencari pasangan, teknik bertukar pasangan, teknik berpikir berpasangan berempat, teknik berkirim salam dan soal, teknik kepala bernomor, teknik dua tinggal dua tamu, teknik keliling kelompok, teknik keliling kelas, teknik kancing gemerincing, teknik jigsaw dan teknik-teknik lainnya yang relevan dengan kompetensi dasar yang ingin dicapai. ${ }^{19}$

Pedagogi antikorupsi di Sekolah Menengah Pertama (selanjutnya disebut SMP) dan Sekolah Mengah Atas (selanjutnya disebut SMA) dapat menggunakan model penelitian sosial, simulasi, brainstorming, studi kasus, silang pendapat, problem-centered group, seminar group, syndicate group, debat, team-quiz, poster dan model-model lain yang relevan dengan kompetensi dasar yang ingin dicapai. ${ }^{20}$ Sama halnya dengan Perguruan Tinggi, konsep pedagogi antikorupsi dapat diintegrasikan ke dalam mata kuliah Pendidikan Pancasila, Pendidikan Kewarganegaraan, Pendidikan Agama, Bahasa Indonesia, Ilmu Sosial Dasar, Ilmu Budaya Dasar, atau dapat dijadikan sebagai mata kuliah tersendiri. ${ }^{21}$

Pemikiran lain mengenai strategi anti korupsi melalui pendekatan pendidikan formal dapat dilakukan melalui pendidikan berkarakter sebagai upaya penyelenggaraan pendidikan anti-korupsi. Kurikulum pendidikan antikorupsi merupakan konsep yang menanamkan nilai-nilai anti korupsi. Seperti, konsep mata pelajaran tersendiri, konsep terintegrasi dalam semua mata pelajaran, luar pembelajaran, konsep pembudayaan, pembiasaan nilai dalam

\footnotetext{
${ }^{19}$ Ibid., hal 50.

${ }^{20} \mathrm{Ibid}$.

${ }^{21}$ Ibid., hal 51.
} 
seluruh aktivitas dan suasana sekolah, dan kosep gabungan. Sedangkan untuk metode atau cara penyampaian nilai-nilai anti korupsi, dapat dilakukan dengan metode demokratis, pencarian bersama, siswa aktif atau aktivitas bersama, keteladanan, live in, dan penjernihan nilai atau klarifikasi nilai. ${ }^{22}$

Uraian di atas sebagai contoh penerapan pedagogi antikorupsi di sekolah sampai perguruan tinggi melalui jalur pembelajaran saja. Pedagogi antikorupsi dapat diwujudkan melalui kegiatan lomba tulis, baca puisi antikorupsi, lomba poster antikorupsi, lomba pidato antikorupsi, lomba geguritan antikorupsi, lomba dongeng antikorupsi, lomba kisah antikorupsi, lomba tulis cerpen antikorupsi, drama antikorupsi, lomba debat tentang korupsi, dan kegiatan lain yang lebih cair, segar, menyenangkan, bebas, menarik, menantang dan mendidik.

Komparatif dengan berbagai negara, misalnya Negara Finlandia yang terbilang relatif bersih dari korupsi. Ada tiga faktor utama yang menyebabkan Finlandia bersih dari korupsi. Pertama, obedience, yaitu sikap taat atau patuh pada hukum. Kedua, honesty, yaitu sikap jujur pada diri sendiri dan orang lain. Ketiga, life style atau gaya hidup sederhana dan tidak konsumtif. Di Finlandia, sikap bohong tidak disukai oleh rakyat. ${ }^{23}$

Menarik untuk diperhatikan dari pengalaman Hongkong dalam hal menangani korupsi dinegaranya, dikatakan oleh Mr Raymond H. C. WONG bahwa: ${ }^{24}$

Since its inception in 1974, the Independent Commission Against Corruption (commonly known as the ICAC) has witnessed the rapid economic development of Hong Kong. As Hong Kong develops into a metropolitan city and a major financial centre, the crime of corruption has also grown in complexity. Nowadays it very often forms part and parcel of other organized and serious crimes. With the rise of

\footnotetext{
${ }^{22}$ Ahmad Zuber, "Strategi Anti Korupsi melalui Pendekatan Pendidikan Formal dan KPK (Komisi Pemberantasan Korupsi)", Journal of Development and Social Change, Vol. 1, No. 2, Oktober 2018, Fakultas Ilmu Sosial dan Politik Universitas Sebelas Maret, 2018, Surakarta, hal 189.

${ }^{23}$ Bambang Suryadi, “Belajar dari Pemberantasan Korupsi di Negara Lain”, CSRC UIN Syarif Hidayatullah, 2006, Jakarta, hal 192.

${ }^{24} \mathrm{Mr}$ Raymond H. C. WONG dalam Herlambang, "Belajar menanggulangi Korupsi dari Negara Lain", Jurnal Hukum Supremasi Hukum Nomor 2 (23) Agustus 2012, Fakultas Hukum Unversitas Bengkulu, 2012, Bengkulu, hal 2.
} 
"Globalization" and the "Knowledge-based Economy" due to the advance of information technology, criminals round the world are now able to plan and execute a wide range of illicit activities through the internet or other means of mobile communication facilities. Many corrupt activities have transformed into cross-border crimes. Criminals are also able to escape justice by speedily moving around different places, taking advantage of the convenience of rapid modern-day travel. In the face of the challenge of hi-tech and internationalized corrupt activities, how to tackle cross-border crimes has become an important issue of common concern amongst law enforcement agencies worldwide. The ICAC has always paid serious attention to the need of international cooperation in combating corruption and organized crime. Our strategy focuses on three areas: law enforcement cooperation, experience sharing, and staff training.

Hal di atas, pada esensinya Hongkong mendirikan Komisi Independen Anti Korupsi (umumnya dikenal sebagai ICAC) pada tahun 1974. Ketika Hongkong berkembang menjadi kota metropolitan dan pusat keuangan utama, kejahatan korupsi juga tumbuh dalam kompleksitas. Munculnya Era "Globalisasi" dan "Ekonomi Berbasis Pengetahuan" dengan kemajuan teknologi informasi, penjahat di seluruh dunia sekarang dapat merencanakan dan melaksanakan berbagai kegiatan terlarang melalui internet atau sarana komunikasi seluler lainnya. Banyak kegiatan korupsi telah berubah menjadi kejahatan lintas batas. Penjahat juga dapat melarikan diri dari keadilan dengan bergerak cepat di berbagai tempat dengan cepat. Menghadapi tantangan itu, cara untuk mengatasi kejahatan lintas batas telah menjadi isu penting bersama di antara lembaga penegak hukum di seluruh dunia. ICAC selalu memberikan perhatian serius pada kebutuhan kerjasama internasional dalam memerangi korupsi dan kejahatan terorganisir. Strategi kami berfokus pada tiga bidang: kerjasama penegakan hukum, berbagi pengalaman, dan pelatihan staf.

Selain itu, konsep keberhasilan China memberantas korupsi adalah adanya penegakan hukum yang tegas, China memiliki badan antikorupsi, yaitu Anti Corruption Branch (ACB) yang ditangani oleh kepolisian. Oleh karena ACB dikelola oleh kepolisian yang sudah mendapatkan stigma korup, maka ACB tidak direspon masyarakat. Itulah sebabnya, ACB diganti menjadi Anti 
Corruption Office (ACO) yang dipimpin oleh pemimpin baru yang betul-betul jujur. ACO memiliki tiga bagian, yaitu:

a. Bagian pengumpul keterangan intelijen yang telah lama ada;

b. Bagian penyidikan tuduhan korupsi sehari-hari; dan

c. Bagian penyidikan terhadap pegawai pemerintah yang mempunyai kekayaan yang jauh melampaui gaji mereka. ${ }^{25}$

Selanjutnya Negara Malaysia semula adalah negara dengan sistem feodal agraris. Sejak dijajah Inggris, sistem feodal tersebut berubah menjadi perserikatan berbasis demokrasi dengan model Inggris. Meskipun menggunakan model Inggris, sisa-sisa feodalisme di Malaysia masih tampak, yakni adanya praktik pemberian upeti yang menjadi lahan subur berkembangnya korupsi. Dalam rangka membangun negara modern yang bebas korupsi, sejak tahun 1961 Malaysia mengeluarkan Undang-Undang Antikorupsi yang dikenal dengan nama Prevention of Corruption Act atau Akta Pencegahan Rasuah 57. Strategi yang dilakukan oleh Badan Pencegah Rasuah (BPR) yaitu: ${ }^{26}$

a. strategi pengukuhan, dimana untuk meningkatkan efektivitas BPR, strategi pengukuhan memberi kekuatan kepada profesionalisme BPR dan meningkatkan kerjasama dengan penegak hukum antikorupsi internasional dan media massa;

b. Strategi penggalakan dan pencegahan, yang menekankan pada usaha-usaha penghayatan nilai-nilai murni, pencegahan korupsi, dan peningkatan sistem supervisi yang tegas dalam penegakan peraturan perundang-undangan;

c. Strategi penegakan hukum, yaitu melalui pembalikan beban pembuktian kepada tersangka yang terbukti memiliki harta benda yang berlebihan dibandingkan dengan pendapatannya, perampasan harta yang tidak dapat dijelaskan asal-usulnya, dan meningkatkan ketegasan penegakan undangundang yang memberi dampak pada pencegahan korupsi. ${ }^{27}$

Melihat hal-hal di atas, jelas kiranya negara-negara maju mempunyai strateginya masing-masing dalam pemberantasan korupsi. Indonesia membentuk Komisi Pemberantasan Korupsi (selanjutnya disebut KPK), KPK

\footnotetext{
${ }^{25}$ Bambang Suryadi, “Belajar dari Pemberantasan...”, op.cit., hal 195.

${ }^{26}$ Ibid., hal 39-40.

${ }^{27}$ Ibid.
} 
adalah lembaga negara yang dalam melaksanakan tugas dan wewenangnya bersifat independen dan bebas dari pengaruh kekuasaan manapun. ${ }^{28}$ Dibentuknya KPK dengan tujuan meningkatkan daya guna dan hasil guna terhadap upaya pemberantasan tindak pidana korupsi. ${ }^{29}$ Apabila ditinjau dari perbedaan kelembagaan negara-negara maju di atas membentuk suatu lembaga khusus dalam penanganan korupsi. Akan tetapi di Indonesia terdapat tiga lembaga yang mempunyai otoritas dalam pemberantasan tindak pidana korupsi yaitu, Kepolisian, Kejaksaan dan KPK, hal ini menjadi kesan bahwa kewenangan dalam hal penanganan korupsi di Indonesia menjadi tumpang tindih.

Selain itu ditinjau dari rencana strategi yang termaktub dalam Pasal 26 Undang-Undang Nomor 30 Tahun 2002 tentang Komisi Pemberantasan Korupsi dalam pelaksanaannya selalu berubah-ubah dan tidak berkesinambungan. Berbeda dengan ICAC, bahwa dalam rencana strategisnya terfokus pada departemen yang sudah ditentukan dengan pola kerjasama penegakan hukum, berbagi pengalaman, dan pelatihan staf.

Lebih dari itu di China, strategi dalam upaya pemberantasan korupsi dengan penegakan hukum yang tegas. Sedangkan KPK dalam penegakan hukum harus membagi kewenangannya dengan kepolisian atau sebaliknya, hal ini dapat dilihat dari maksud dan tujuan dari Undang-Undang KPK inkonsisten dengan ketentuan Undang-Undang Kepolisian dan Kejaksaan. Misalnya, dalam konteks penyidikan dan penuntutan yang semula menjadi kewenangan Kepolisian dan Kejaksaan sepertinya telah memberikan peluang akan tak terbatasnya kewenangan KPK, meskipun jumlah satu milyar rupiah (Pasal 11 UU KPK) cukup jelas. Namun, dalam arti pembagian dan pemisahan kewenangan tampak kurang konsisten. Hal itu sungguh memprihatinkan ketika penegakan hukum, khususnya kepolisian, kejaksaan, dan pengadilan tidak

\footnotetext{
${ }^{28}$ Pasal 3 Undang-Undang Nomor 30 Tahun 2002 tentang Komisi Pemberantasan Korupsi

${ }^{29}$ Pasal 4 Undang-Undang Nomor 30 Tahun 2002 tentang Komisi Pemberantasan Korupsi
} 
kompak dalam melaksanakan tugasnya menerapkan hukum terhadap suatu kasus yang sedang diimpikan masyarakat.

Harapan yang dituangkan dalam legalitas formal merupakan suatu konsep yang sangat baik, akan tetapi dalam kenyataannya sering terjadi tidak singkronnya anatara harapan dan kenyataan. Butuh suatu usaha yang bisa mewujudkan pencegahan korupsi melalui sarana pendidikan. Usaha yang dilakukan adalah melakukan perubahan sosial yang dimulai dengan perubahan cara berpikir. Hal ini akan mustahil jika ingin ada perubahan ke arah yang benar kalau kesalahan berpikir masih menjebak masyarakat.

Teringat dua bait puisi yang berbunyi, sekiranya kucing-kucing miskin diberikan sayap, maka kucing itu akan terbang dan menghabiskan semua telur burung pipit. Bait tersebut mengajarkan bagaimana perubahan sosial pada tingkat individu dapat berpengaruh pada perubahan perilaku orang lain. Maka tidak benar bahwa kalau orang miskin diberi kekayaan akan menjadi baik. Juga, tidak benar kalau orang kaya dijarah lalu menjadi miskin akan berubah menjadi menjadi baik. Semua itu tergantung pada sumber daya manusianya.

Saat ini, pada kebanyakan rakyat Indonesia telah terjadi perubahan norma-norma secara administrative. Maksudnya adalah perubahan norma yang terjadi sebagai dampak dari perubahan organisasi sosial (perubahan prosedur) bukan kesalahan prosedur. Misalnya seorang PNS harus berhadapan dengan ketentuan bahwa bantuan dari pemerintah hanya diberikan kepada anak pertama dan kedua, selebihnya dari itu di luar tanggung jawab pemerintah. Berkaca dengan hal tersebut bisa saja atau patut diduga seseorang melakukan tindak pidana korupsi agar memenuhi segala kebutuhan hidupnya.

Salah satu cara yang bisa dilakukan untuk menanggulangi kejahatan melalui non-penal dengan mengedepankan konsep pedagodi antikorupsi melalui strategi persuasif (persuasive strategy). Dalam strategi ini, media massa bisa sangat berperan, karena pada umumnya strategi ini dijalankan melalui pembentukan opini dan pandangan masyarakat yang tidak lain melalui media massa. 
Lebih lanjut strategi dalam penelitian ini penulis mengusulkan strategi normative-reeducation (normatif-reedukatif) yang dapat diartikan suatu aturan yang berlaku di masyarakat. Norma termasyarakatan lewat education (pendidikan). Oleh sebab itu, strategi normatif ini digandengkan dengan upaya reeducation (pendidikan ulang) untuk menanamkan dan mengganti paradigma masyarakat tentang bahaya korupsi bagi segala lini aspek kehidupan.

Setelah melihat konsep pendidikan untuk menanggulangi kejahatan korupsi yang sasarannya meliputi pendidikan formal, maka selanjutnya perlu dipahami mengenai pendidikan bagi orang tua dalam mengelola penggunaan kekayaan. Sudah dijelaskan sebelumnya bahwa orang miskin ketika menjadi kaya belum tentu akan menjadi baik maupun sebaliknya.

Masyarakat hari ini dalam konteks pikirannya sangat dipengaruhi oleh pola hidup yang berlebihan, tidak menjadi masalah bagi orang-orang yang terlahir dengan kekayaan yang lebih dari cukup, akan tetapi yang menjadi masalah adalah orang yang mempunyai kekayaan cukup harus mengikuti pola hidup orang yang mempunyai keuangan yang berlebih.

Konsep yang bisa dijalankan bagi orang tua atau masyarakat adalah konsep pola tengah penggunaan kekayaan. Hal ini dapat diartikan bahwa penggunaan kekayaan harus memenuhi kewajaran, dalam arti lain kepribadian dan prihatin merupakan unsur solidaritas sosial. Selain itu, solidaritas sosial merupakan sikap yang memperhitungkan dan memperhati kan keadaan dan kepentingan orang banyak. Lebih dari itu harus terdapat keprihatinan dalam menggunakan harta pribadi digunakan sesuai kebutuhan hidup yang wajar, dan menyisihkan sebagian harta kekayaan untuk mendorong produktivitas masyarakat.

\section{PENUTUP}

Berdasarkan uraian di atas, maka dapat diinferensikan yaitu sarana nonpenal memiliki nurani intelektual yang berfokus pada perbaikan kondisi sosial, namun secara implisit mempunyai pengaruh previntif terhadap kejahatan. Penanggulangan kejahatan melalui sarana non-penal harus dilakukan karena sarana penal memiliki kelemahan atau ketidak mampuan hukum pidana dari sudut 
berfungsinya atau bekerjanya hukum (sanksi) pidana itu sendiri. Meniscayakan langkah-langkah penanggulangan kejahatan dengan sarana non-penal maka proses perwujudannya melalui pendidikan yang mempunyai peran kunci. Sebagai contoh pendidikan anti korupsi sejak dini melalui pendidikan formal dalam tingkat SD sampai Perguruan Tinggi, lebih dari itu upaya penangulangan kejahatan melalui non penal dalam konsep pendidikan tidak hanya diberikan kepada orang yang menempuh pendidikan formal saja, tetapi kepada seluruh lapisan masyarakat dengan mensosialisasilkan pola hidup sederhana dan melakukan rekaya sosial dengan tujuan perubahan sosial yang baik. Berdasarkan penarikan inferensi tersebut, maka diberikan saran yaitu pemerintah atau KPK seharusnya membuat perencanaan perubahan sosial (Planned Social Change) walaupun perubahan sosial terkadang tidak dalam proses perencanaan akan tetapi perubahan sosial akan terjadi dengan sendirinya. Usaha membuat rencana perubahan sosial merupakan langkah awal untuk mengubah cara berpikir masyarakat. Lebih dari itu pemerintah melalui Komisi Pemberantasan Korupsi dan stakeholder terkait untuk membuat konsep pendidikan anti korupsi masuk dalam lini kehidupan masyarakat.

\section{DAFTAR PUSTAKA}

\section{Buku:}

Bambang Suryadi, “Belajar dari Pemberantasan Korupsi di Negara Lain”, CSRC UIN Syarif Hidayatullah, 2006, Jakarta.

Barda Nawawi Arief, “Bunga Rampai Kebijakan Hukum Pidana Perkembangan Penyusunan Konsep KUHP Baru”, Genta Publishing, 2010, Jakarta.

Eko Handoyono, "Pendidikan Anti Korupsi", Ombak, 2013, Yogyakarta.

UNODC, "ANTI-CORRUPTION EDUCATION AT SCHOOL Methodical Material For General And Higher Education Schools", UNODC, 2006, Wina.

Widiada Gunakaya, "Politik Kriminal”, STHB, 1997, Bandung.

\section{Jurnal:}

Ahmad Zuber, "Strategi Anti Korupsi Melalui Pendekatan Pendidikan Formal dan KPK (Komisi Pemberantasan Korupsi)", Journal of Development and Social Change, Vol. 1, No. 2, Oktober 2018, Fakultas Ilmu Sosial dan Politik Universitas Sebelas Maret, 2018, Surakarta.

Andi Febriansyah Al Sabah AZ, Kebijakan Hukum Pidana Dalam Pemberantasan Tindak Pidana Korupsi, Jurnal Al Daulah Vol 6 No 1, Universitas Islam Negeri Alaudin, 2017, Makassar. http://dx.doi.org/10.24252/ad.v6i1.4875 
Herlambang, "Belajar Menanggulangi Korupsi Dari Negara Lain”, jurnal Hukum Supremasi Hukum Nomor 2 (23) Agstus 2012, Fakultas Hukum Unversitas Bengkulu, 2012, Bengkulu.

Herman, "Upaya Non Penal dalam Penanggulangan Tindak Pidana Korupsi", Horlev Volume 2 Issue 1 March 2018, Fakultas Hukum Universitas Halu Oleo, 2018, Kendari. http://dx.doi.org/10.33561/holrev.v2i1.4192

Japansen Sinaga, "Kebijakan Penegakan Hukum Dalam Tindak Pidana Korupsi Berdasarkan Pendekatan Non-Penal', Jurnal Law Pro Justitia Vol. II, No. 2 - Juni 2017, Fakultas Hukum Universitas Pelita Harapan, 2017, Medan.

Mahmud Mulyadi "Penanggulangan Tindak Pidana Korupsi dalam Perspektif Criminal Policy (Corruption Reduction In Criminal Policy Perspective)", Jurnal Legislasi Indonesia, Vol. 8 No 2 - Juni 2011, Kementerian Hukum dan HAM, Jakarta.

Mas Putra Zenno Januarsyah, "Penerapan Prinsip Ultimum Remedium dalam Tindak Pidana Korupsi Kajian Putusan Nomor 2149 K/Pid.Sus/2011", Jurnal Yudisial Vol 10 No 3 Desember 2017, Komisi Yudisial, 2017, Jakarta. http://dx.doi.org/10.29123/jy.v10i3.266

Rangga Jayanuarto, "Kebijakan Non Penal (Penanggulangan Korupsi) Berdimensi Transendental", Prosiding Seminar Nasional 2018, Universitas Muhammadiyah Surakarta, 2018, Surakarta.

Tamala Sari Martha Prakoso, "Pemenuhan unsur memperkaya diri sendiri atau orang lain atau Korporasi dalam pasal 2 uu nomor 31 tahun 1999 dan unsur Menguntungkan diri sendiri atau orang lain atau korporasi dalam pasal 3 uи nomor 31 tahun 1999 pada putusan hakim Perkara tindak pidana korupsi (Studi Putusan Nomor 238/Pid.b/2009/PN.Kray jo. Nomor 373/Pid.b/2010/PT.Smg jo. Nomor 167k/Pid.sus/2011 di Pengadilan Negeri Karanganyar)", Recidive Volume 3 No 1 Januari-April 2014, Fakultas Hukum Universitas Sebelas Maret, 2014, Surakarta.

Totok Suyanto, "Pendidikan Anti Korupsi dan Pengembangan Budaya Sekolah", JPIS Vol 23 No 8 Edisi Juli - Desember 2005, Jurnal Pendidikan Ilmu Sosial, Bandung, 2005.

\section{Undang-Undang}

Undang-Undang Nomor 31 Tahun 1999 Jo. Undang-Undang Nomor 20 Tahun 2001 tentag Pemberantasan Tindak Pidana Korupsi.

Undang-Undang Nomor 30 Tahun 2002 Jo. Undang-Undang Nomor 19 Tahun 2019 tentang Komisi Pemberantasan Korupsi

\section{Internet:}

https://ti.or.id/corruptionperception-index-2018/

https://www.kpk.go.id/id/ 